\title{
GAMBARAN NILAI HEMATOKRIT DAN LAJU ENDAP DARAH PADA ANAK DENGAN INFEKSI VIRUS DENGUE DI MANADO
}

\author{
${ }^{1}$ Sitti S. P. Kamuh \\ ${ }^{2}$ Arthur E. Mongan \\ ${ }^{2}$ Maya F.Memah
}

\author{
${ }^{1}$ Kandidat Skripsi Fakultas Kedokteran Universitas Sam Ratulangi Manado \\ ${ }^{2}$ Bagian Patologi Klinik Fakultas KedokteranUniversitas Sam Ratulangi Manado \\ Email: pratiwi.usman@yahoo.com
}

\begin{abstract}
Dengue is a major public health problem that can be found throughout the tropical and subtropical countries around the world. Spectrum of clinical manifestations of dengue virus infection varies greatly. In addition to clinical symptoms, the diagnosis of dengue virus infection need to be supported by blood tests such as hematocrit and erythrocyte sedimentation rate. This study aimed to determine the hematocrit value and erythrocyte sedimentation rate (ESR) in children with dengue virus infection in Manado. This study used a cross-sectional design and was conducted from Desember 2014 to January 2015 at GMIM Pancaran Kasih, Advent, and Robert Wolter Mongisidi hospitals in Manado. There were 37 patients that fulfilled the inclusion criteria, consisted of 17 males and 20 females. The results showed that of 37 patients, there were 36 with hematocrit within normal limits. Moreover, of 37 patients only 6 patients performed the ESR examination; only 1 child had a rapid ESR result (> $15 \mathrm{~mm} / \mathrm{h})$. Conclusion: In this study, most of the pediatric patients with dengue virus infection in Manado had normal hematocrit. Of 6 patients who had performed ESR test, only 1 had rapid ESR.
\end{abstract}

Keywords: dengue, hematocrit, erythrocyte sedimentation rate

\begin{abstract}
Abstrak: Dengue merupakan masalah kesehatan masyarakat yang utama dan dapat ditemui diseluruh daerah tropis dan subtropis di seluruh dunia. Spektrum manifestasi klinis infeksi virus dengue sangat bervariasi. Selain gejala klinis, diagnosis infeksi virus dengue perlu ditunjang hasil uji darah di laboratorium antara lain hematokrit dan laju endap darah (LED). Penelitian ini bertujuan untuk mengetahui nilai hematokrit dan LED pada anak dengan infeksi virus dengue di Manado. Penelitian ini menggunakan desain potong lintang, dilakukan pada bulan Desember 2014 sampai Januari 2015 di RSU GMIM Pancaran Kasih Manado, RS Advent Manado, dan RSAD Robert Wolter Mongisidi Teling17 anak laki-laki dan 20 anak perempuan. Hasil penelitian memperlihatkan 36 dari 37 pasien mempunyai hematokrit normal. Dasri 37 pasien, hanya 6 anak yang menjalani pemeriksaan LED; hanya 1 anak dengan LED cepat (> 15mm/jam). Simpulan: Pada studi ini, sebagian besar pasien anak dengan infeksi virus dengue di Manado mempunyai nilai hematokrit normal. Dari 6 pasien yang dilakukan pemeriksaan LED, 1 anak mempunyai hasil LED cepat.
\end{abstract}

Kata kunci: dengue, hematrokrit, laju endap darah.

Dengue adalah penyakit yang ditularkan oleh nyamuk yang disebabkan salah satu dari empat jenis virus dengue. Setiap jenis virus dengue mampu menyebabkan spektrum penyakit dari infeksi tanpa gejala sampai menjadi parah, penyakit yang mengancam jiwa ini termasuk demam berdarah dengue (DBD) dan dengue shock syndrome (DSS). Dengue adalah masalah kesehatan masyarakat yang utama dapat 
ditemui diseluruh daerah tropis dan subtropis di seluruh dunia. ${ }^{1}$ Dimana organisasi kesehatan dunia (WHO) melaporkan 100 juta kasus dengue setiap tahun, dengan kurang lebih 2,5 miliyar manusia berisiko terjangkit penyakit ini sehingga membuat penyakit ini sebagai satu dari penyakit virus terpenting didunia yang utamanya terjangkit di negara tropis dan subtropis. ${ }^{2}$

Di Indonesia pertama kali dicurigai di Surabaya pada tahun 1968. Di Jakarta kasus pertama dilaporkan pada tahun 1969, kemudian DBD berturut-turutdilaporkan di Bandung, Yogyakarta, Sumatra barat dan Lampung pada tahun 1972 dan disusul oleh Riau, Sulawesi Utara dan Bali pada tahun 1973. Pada tahun 1993 DBD telah menyebar ke seluruh Propinsi di Indonesia. $^{3}$

Kasus demam berdarah dengue di Sulawesi utara tahun 2008 sampai 2012 dilaporkan banyak terjadi pada bulan Februari dengan 322 kasus, kedua terbanyak pada bulan Januari dengan 243 kasus, Maret 202 kasus, Desember 126 kasus, Agustus 120 kasus, April 96 kasus, Juli 82 kasus, September 73 kasus, Mei 69 kasus, Juni dan November 61 kasus, dan Oktober 41 kasus. $^{4}$

Spekrum manifestasi klinis infeksi virus dengue sangat bervariasi mulai dari asimtomatis, demam ringan yang tidak spesifik, demam dengan demam berdarah dengue, hingga sindrom syok dengue, serta ensefalopati dengue. ${ }^{5}$ Virus dengue termasuk graoup B arthropod borne virus (arboviruses) dan sekarang dikenal sebagai genus falvivirus, famili Flaviviridae, yang mempunyai 4 jenis serotipe yaitu DEN-1, DEN-2, DEN-3, DEN-4. Keempat jenis serotipe virus dengue dapat ditemukan di berbagai daerah di Indonesia. $^{3}$

Diagnosis infeksi virus dengue, di samping gejala klinis, perlu ditunjang hasil uji darah di laboratorium. Gambaran khas hasil laboratorium DBD adalah terjadi peningkatan hematokrit (meningkat 20\%, atau nilai hematokrit lebih 3,5 kali nilai $\mathrm{Hb})$ disertai penurunan trombosit kurang dari $100.000 / \mu L$. Perubahan ini sering terjadi pada hari ke-3 hingga ke-5 panas.Pemeriksaan penunjang lain yang sering dilakukan adalah uji untuk mengenali antibodi spesifik virus dengue baik imunoglobulin M (IgM) anti dengue untuk infeksi dengue primer maupun imunoglobulin G (IgG) untuk diagnosis infeksi dengue sekunder. Pemeriksaan serologi antibodi IgM anti dengue ataupun IgG anti dengue akan mempertajam diagnosis DBD. ${ }^{6}$

Pemeriksaan hematokrit bertujuan untuk mengetahui adanya hemokonsentrasi yang terjadi pada penderita DBD. Hematokrti adalah volume (dalam mililiter) sel darah merah yang ditemukan di dalam $100 \mathrm{ml}(1 \mathrm{dl})$ darah, dihitung dalam persentase. Kadar hematokrit yang rendah sering ditemukan pada kasus anemia dan leukimia, dan peningkatan kadar ditemukan pada dehidrasi dan pada polisetemia vera. Peningkatan kadar hematokrit dapat mengindikasikan hemokonsentrasi, akibat penurunan volume cairan dan peningkatan sel darah merah. ${ }^{7,8}$

Pemeriksaan laju endap darah (LED) mengukur derajat endap eritrosit dalam suatu sampel darah selama periode waktu tertentu. LED adalah uji yang sensitif tapi tidak spesifik. ${ }^{9}$ Selama tahap DBD, berbagai infeksi bakteri dapat menjadi bagian dari diagnosis diferensial, dalam hal ini tingkat endap darah sangat berguna, karena nilai-nilai infeksi pada pasien DBD tidak tetap. $^{1}$

\section{METODE PENELITIAN}

Penelitian ini menggunakan metode analitik observasional dengan desain potong lintang. Penelitian dilakukan di 3 rumah sakit, yaitu: RSU Pancaran Kasih GMIM Manado, RS Wolter Mongisidi Manado, dan RS Advent Manado. Pemeriksaan nilai hematokrik dan laju endap darah dilakukan pada laboratorium Prokita Malalayang.

Variabel terikat ialah anak dengan infeksi virus dengue sedangkan variabel bebas ialah nilai hematokrit dan LED. Sampel diambil dengan non-probability sampling jenis consecutive sampling untuk 
mendapatkan darah dari 37 anak terinfeksi virus dengue yang memenuhi kriteria inklusi dan ekslusi.

Alat dan bahan yang digunakan ialah darah pungsi vena, alat mikro-sentrifus, dan tabung Westergren.

\section{HASIL PENELITIAN}

Pada bulan Desember 2014 sampai Januari 2015 diperoleh sampel sejumlah 37 anak terinfeksi virus dengue yang memenuhi kriteria inklusi.

Tabel 1. Distribusi anak terinfeksi virus dengue berdasarkan jenis kelamin

\begin{tabular}{ccc}
\hline Jenis Kelamin & Frekuensi & $\mathbf{( \% )}$ \\
\hline Laki-laki & 20 & 54,1 \\
Perempuan & 17 & 45,9 \\
Jumlah & 37 & 100 \\
\hline
\end{tabular}

Tabel 2. Distribusi anak terinfeksi virus dengue berdasarkan usia

\begin{tabular}{ccc}
\hline Usia sampel & $\begin{array}{c}\text { Jumlah } \\
\text { anak }\end{array}$ & \%) \\
\hline Usia $<1$ tahun & 1 & 2,7 \\
Usia 1-4 tahun & 6 & 16,2 \\
Usia 5-14 tahun & 30 & 81,1 \\
Jumlah & 37 & 100 \\
\hline
\end{tabular}

Tabel 3. Anak terinfeksi virus dengue berdasarkan IMT

\begin{tabular}{ccc}
\hline Status IMT & Frekuensi & $(\%)$ \\
\hline Kurus & 7 & 18,9 \\
Normal & 27 & 73,0 \\
Gemuk & 3 & 8,1 \\
Jumlah & 37 & 100 \\
\hline
\end{tabular}

Tabel 4. Anak terinfeksi virus dengue berdasarkan lamanya demam

\begin{tabular}{ccc}
\hline Lama demam & Frekuensi & $\mathbf{( \% )}$ \\
\hline 3 hari & 21 & 56,8 \\
4 hari & 5 & 13,5 \\
5 hari & 11 & 29,7 \\
Jumlah & 37 & 100 \\
\hline
\end{tabular}

Tabel 5. Sebaran pasien berdasarkan kecamatan

\begin{tabular}{lcc}
\hline Kecamatan & Frekuensi & $\mathbf{( \% )}$ \\
\hline Pineleng & 5 & 13,5 \\
Dimembe & 3 & 8,1 \\
Wanea & 10 & 27,0 \\
Malalayang & 4 & 10,8 \\
Girian & 1 & 2,7 \\
Tikala & 5 & 13,5 \\
Sario & 2 & 5,4 \\
Mapangat & 5 & 13,5 \\
Kalawat & 1 & 2,7 \\
Singkil & 1 & 2,7 \\
\hline Jumlah & 37 & 100 \\
\hline
\end{tabular}

Tabel 6. Sebaran pasien berdasarkan kabupaten/Kota

\begin{tabular}{lcc}
\hline Kabupaten & Frekuensi & $\mathbf{( \% )}$ \\
\hline Minahasa & 5 & 13,5 \\
Minahasa Utara & 4 & 10,8 \\
Manado & 27 & 73,0 \\
Bitung & 1 & 2,7 \\
\hline Jumlah & 37 & 100 \\
\hline
\end{tabular}

Tabel 7. Nilai Hematokrit

\begin{tabular}{|c|c|c|}
\hline Nilai Hematokrit & Frekuensi & $(\%)$ \\
\hline $\begin{array}{l}\text { Hematokrit rendah } \\
(<35 \%)\end{array}$ & 13 & 35,1 \\
\hline Normal (35-47\%) & 23 & 62,2 \\
\hline $\begin{array}{l}\text { Hematokrit tinggi } \\
(>47 \%)\end{array}$ & 1 & 2,7 \\
\hline Jumlah & 37 & 100 \\
\hline
\end{tabular}

Tabel 8. Anak terinfeksi virus dengue berdasarkan LED

\begin{tabular}{lc}
\hline Jenis kelamin & Frekuensi \\
\hline Laki-Laki $(<15 \mathrm{~mm} / \mathrm{jam})$ & 3 \\
Laki-Laki $(>15 \mathrm{~mm} / \mathrm{jam})$ & 1 \\
Perempuan $(<20 \mathrm{~mm} / \mathrm{jam})$ & 2 \\
Jumlah & 6 \\
\hline
\end{tabular}

Tabel 9. Distribusi pemeriksaan laboratorium

\begin{tabular}{lcc}
\hline Jenis Pemeriksaan & Jumlah & $\mathbf{( \% )}$ \\
\hline NS-1 & 22 & 59,5 \\
IgG (+) / IgM (-) & 14 & 37,8 \\
IgG (-) / IgM (+) & 1 & 2,7 \\
Jumlah & 37 & 100 \\
\hline
\end{tabular}




\section{BAHASAN}

Penelitian ini dilakukan di kota Manado pada bulan November 2014 sampai dengan Januari 2015. Pengambilan sampel di lakukan di rumah sakit sekunder yang mencakup 3 rumah sakit, RS Pancaran Kasih GMIM Manado, RS Wolter Mongisidi Manado, dan RS Advent Manado. Pemeriksaan NS-1, IgG IgM, dan pemeriksaan hematologi darah lainnya dilakukan di laboratorium Prokita malalayang Manado.

Selama November 2014 - Januari 2015 didapatkan usia paling muda 10 bulan dan tertua 14 tahun dengan kelompok usia pada anak $<15$ tahun sebagai kelompok paling banyak terkena (81,1\%). Penelitian ini tidak berbeda dengan penelitian yang dilakukan di RSUP Dr. Cipto Mangunkusumo pada tahun 2007 sampai 2009 mendapatkan hasil dari kelompok usia 5-10 tahun (41\%). ${ }^{10}$

Berdasarkan jenis kelamin dari penelitian yang di dapat perempuan (45,9\%) dan laki-laki (54,1\%). Sama dengan penelitian yang dilakukan oleh Hartoyo didapatkan jenis kelamin laki-laki lebih banyak 66 (54,6\%) dibandingkan dengan perempuan hanyak $57(45,4 \%){ }^{11}$

Distribusi berdasarkan indeks massa tubuh pada anak, dari hasil yang di dapat anak yang terinfeksi virus dengue terdapat 37 orang IMT normal (73.0\%), 7 orang IMT kurus (18,9\%), dan 3 orang IMT gemuk $(8,1 \%)$. Pada penelitian lain tidak didapat perbedaan yang dilakukan di RSUP. Dr. Wahidin Sudirohusodo Makassar tahun 2012 mendapatkan bahwa IMT normal 86.8\%, bahwa status gizi anak adalah keadaan kesehatan anak yang ditentukan oleh derajat kebutuhan fisik energi dan zat-zat gizi lain yang diperoleh dari pangan dan makanan. ${ }^{12}$

Berdasarkan demam pada penelitian ini, dari 37 anak terinfeksi virus dengue. Demam hari ketiga terdapat 21 orang (56,8\%), 9 orang hari keempat $(24,3 \%)$, dan 7 orang hari kelima (18,9\%). Hal ini agak berbeda dengan penelitian sebelumnya di Bagian Anak RSUP. Dr. Kariadi Semarang dari tahun 2010 hingga
2011 didapatkan demam 5-7 hari. ${ }^{13}$

Peningkatan hematokrit merupakan menifestasi hemokonsentrasi yang terjadi akibat kebocoran plasma ke ruang ekstravaskuler disertai efusi cairan serosa, melalui kapiler yang rusak. Peningkatan nilai hematokrit atau hemokonsentrasi selalu dijumpai pada DBD, dan merupakan indikator yang peka akan terjadinya perembesan plasma. Hemokosentrasi dengan peningkatan hematokrit $20 \%$ atau lebih (misalnya dari 35\% menjadi 42\%) mencerminkan peningkatan permeabilitas kapiler dan perembesan plasma. ${ }^{14}$ Berdasarkan data yang diperoleh nilai hematokrit terendah (35\%), nilai hematokrit normal (62\%), dan yang memliki nilai hematokrit tinggi (3\%). Penelitian sebelumnya oleh Rasyada et al. ${ }^{15}$ melaporkan hasil berbeda yaitu nilai hematokrit rendah $30 \%$, nilai hematokrit normal 42\%, dan tinggi 59\%. Pada umumnya nilai hematokrit dipengaruhi oleh pengantian cairan atau perdarahan. ${ }^{14}$

Untuk pasien DBD yang memiliki nilai LED, dari 37 sampel hanya didapatkan 6 sampel dikarenakan jumlah darah yang terlalu sedikit. Dari 6 sampel didapatkan 4 orang anak laki-laki dan 2 orang anak perempuan. Dari 6 sampel 4 yang memiliki nilai normal laju endap darah, 1 memiliki LED lambat, dan 1 memiliki laju endap darah cepat. Pada penelitian sebelumnya di Brasil tidak terdapat perbedaan hasil dari 180 pasien dengan demam berdarah dengue, terdapat nilai LED normal 77\%. ${ }^{1}$ Umumnya pasien yang memiliki penyakit yang berhubungan dengan demam berdarah paling sering mengalami infeksi saluran kencing dan anemia. Laju endap darah akan meningkat pada infeksi saluran kencing karena produksi lebih besar dari protein oleh hati pada fase akut peningkatan agregaasi akibat eritrosit. ${ }^{16}$

\section{SIMPULAN}

Berdasarkan hasil penelitian yang dilakukan di RSU Pancaran Kasih GMIM Manado, RS Wolter Mongisidi Manado, dan RS Advent Manado dapat disimpulkan bahwa anak-anak yang positif terinfeksi 
virus dengue memiliki nilai hematokrit normal sedangkan untuk nilai LED hanya 1 anak yang memiliki nilai LED cepat.

\section{DAFTAR PUSTAKA}

1. Souza LJ, Reis AFF, Almeida FCR, Souza LA, Abukater M, Gomes MAE, et al. Alterations in the erythrocyte sedimentation rate in dengue patients: analysis of 1,398 cases. Braz J Infect Dis. 2008;12(6):3-4.

2. Budiyasa DGA, Merati KTP. Hubungan Antara derajat Berat Infeksi Virus Dengue dan Kadar natrium Serum. J Peny Dalam. 2011;12:22.

3. Poorwo Soedarmo SS, Garna $H$, Hadinegoro SR, Satari HI. Infeksi \& Pediatri Tropis (Edisi ke-2). Jakarta: IDAI, 2012: p. 156.

4. Pondaag K, Tarumingkeng A, Umboh J. Hubungan Antara Tindakan Pencegahan Dengan Kejadian Demam Berdarah Dengue di Kecamatan Malalayang Kota Manado. Manado: Fakultas Kesehatan Masyarakat Universitas Sam Ratulangi, 2014.

5. Suryono. Perbedaan Manifestasi Klinis dan Laboratorium Berdasarkan Jenis Imunologlobulin Pada Penderita Demam [Skripsi]. Surakarta: Universitas Sebelas Maret, 2011.

6. Irwadi D, Arif M, Hardjoeno. Gambaran Serologi IgM-IgG Cepat dan Hematologi Rutin Penderita DBD. Indonesian Journal of Clinical Pathology and Medical Laboratory. 2007;15:2.

7. Purwanto. Pemeriksaan Laboratorium Pada Penderita Demam Berdarah Dengue. Media Litbang Kesehatan. 2002;XII:14
8. Kee JL. Pedoman Pemeriksaan Laboratorium \& Diagnostik (Edisi 6). Kapoh RP, editor. Jakarta: EGC, 2008; p. 232.

9. Kowalak JP. Buku Pegangan Uji Diagnostik (Edisi 3). Mustaqin H, Ramadhani D, editors. Jakarta: EGC, 2010; p. 117.

10.Raihan, Hadinegoro SRS, Tumbelaka AR. Faktor Prognosis Terjadinya Syok pada Demam Berdarah Dengue. Sari Pediatri. 2010;12(1):47-52.

11. Hartoyo E. Spektrum Klinis Demam Berdarah Dengue Pada Anak. Sari Pediatri. 2008;10:146-7.

12.Safitri L, Hasanuddin h, Burhanuddin. Hubungan Status Gizi Dengan Derajat Keparahan Demam Berdarah Dengue (DBD) Pada Anak di RSUP. Dr. Wahidin Sudiro Husodo Makassar. Vol 1 No 52012 ISSN. 2302-1721 2012;1:4-5.

13.Tanra AAM, Arkhaesi N, Hardian. Korelasi Antara Lama Demam Dengan Kadar IgM dan IgG Anak Yang Menderita Demam Berdarah Dengue [Skripsi]. Semarang: Universitas Diponegoro, 2011.

14.Pusparini. Kadar Hematokrit dan Trombosit Sebagai Indikator Diagnosis Infeksi Dengue Primer dan Sekunder. J Kedokter Trisakti. 2004;23(2):54-5.

15.Rasyada A, Nasrul E, Edward Z. Hubungan Nilai Hematokrit terhadap Jumlah Trombosit Pada Penderita Demam Berdarah Dengue. Jurnal Kesehatan Andalas. 2014;3:245.

16.Pang J. Thein TL, Leo TS, Lye DC. Early Clinical and laboratory risk factors of intensive care unit requirement during 2004-2008 dengue epidemics in singapore. BMC Infect Dis. 2014;14:649. 